\title{
Analisis Tujuan Pembelajaran dengan Kompetensi Dasar pada Rencana Pelaksanaan Pembelajaran Dasar Listrik dan Elektronika di Sekolah Menengah Kejuruan
}

\author{
Pramudita Budiastuti $^{*}$, Sunaryo Soenarto ${ }^{2}$, Muchlas $^{3}$, Hanafi Wahyu Ramndani ${ }^{4}$ \\ ${ }_{1,3,4}$ Program Studi Pendidikan Vokasional Teknik Elektronika, Universitas Ahmad Dahlan \\ ${ }^{2}$ Program Studi Pendidikan Teknik Elektro, Universitas Negeri Yogyakarta \\ ${ }^{1}$ pramudita.budiastuti@pvte.uad.ac.id* \\ *corresponding author
}

\begin{tabular}{|c|c|}
\hline$A B S T R A C T$ & Article Info \\
\hline $\begin{array}{l}\text { This study aims to determine the conformity between learning objectives with } \\
\text { basic competencies. This research is a document analysis research. The subject } \\
\text { of this research is the lesson plan of electric power installation engineering } \\
\text { teachers in basic electricity and electronics subjects in vocational high schools } \\
\text { in Yogyakarta. Data collection used document observation sheets that were } \\
\text { filled in by instructional design experts. Document observation sheets were } \\
\text { validated through expert judgments and did the reliability test using Cohen } \\
\text { Kappa. The data analysis technique used descriptive statistics. The results of the } \\
\text { conformity between the design of learning objectives and basic competencies } \\
\text { are classified according to the indicated percentage of mean value of } 65.03 \% \text {. }\end{array}$ & $\begin{array}{r}\text { Article history } \\
\text { Received: Jan. } 14^{\text {th }}, 2021 \\
\text { Revised: May } 28^{\text {th }}, 2021 \\
\text { Accepted: May } 30^{\text {th }}, 2021 \\
\text { Keywords } \\
\text { basic competence, } \\
\text { learning objectives, } \\
\text { lesson plan. }\end{array}$ \\
\hline ABSTRAK & \\
\hline $\begin{array}{l}\text { Penelitian ini bertujuan untuk mengetahui keselarasan tujuan pembelajaran } \\
\text { dengan kompetensi dasar. Penelitian ini merupakan penelitian analisis dokumen. } \\
\text { Subjek penelitian ini adalah Rencana Pelaksanaan Pembelajaran (RPP) guru } \\
\text { teknik instalasi tenaga listrik pada mata pelajaran dasar listrik dan elektronika } \\
\text { SMK di Kota Yogyakarta. Pengumpulan data menggunakan lembar pengamatan } \\
\text { dokumen yang diisi oleh ahli desain instruksional. Lembar pengamatan } \\
\text { dokumen divalidasi melalui expert judgements dan reliabilitas diuji dengan } \\
\text { Cohen Kappa. Teknik analisis data menggunakan statistik deskriptif. Hasil } \\
\text { penelitian keselarasan desain tujuan pembelajaran dengan kompetensi dasar } \\
\text { tergolong sesuai dengan penunjukkan persentase nilai rerata sebesar } 65,03 \% \text {. }\end{array}$ & \\
\hline
\end{tabular}

\section{PENDAHULUAN}

Kebijakan kurikulum menuntut guru untuk mengembangkan Rencana Pelaksanaan Pembelajaran (RPP) secara mandiri. Pada pelaksanaan masih terdapat guru yang tidak mengembangkan RPP secara mandiri. Guru memposisikan diri sebagai konsumen dengan menggunakan dan memanfaatkan hasil rancangan RPP guru lain. Guru cenderung menggunakan RPP siap pakai yang dibuat oleh tim Guru Mata Pelajaran di sekolah (Bariyah, 2014: 459). Guru yang cenderung menggunakan RPP siap pakai menunjukkan bahwa guru belum berupaya memberdayakan kemampuan menulis (Sa'diyah \& Mujahidin, 2015: 66). Guru yang kurang memberdayakan kemampuan menulis ditandai dengan hasil perancangan lesson plan yang sulit dibaca, dipahami, dan diimplementasikan. Perancangan RPP yang sulit dibaca, dipahami, dan diimplementasikan menunjukkan bahwa guru 
kurang mampu mengolah kata menjadi kalimat secara redaksional (Setyawanto, Sunaryo, \& Basuki, 2015: 3-4).

Salah satu indikator RPP yang berkualitas adalah aktivitas guru membuat tujuan pembelajaran sesuai konsep pembelajaran yang diterapkan di sekolah. Tujuan pembelajaran minimal dapat memungkinkan seseorang untuk memiliki kemauan belajar dan meningkatkan keterampilan (Brown \& Green, 2016: 7). Untuk mewujudkan tujuan pembelajaran yang baik, tahap perencanaan sangat penting agar tercipta proses pembelajaran yang maksimal (Haynes, 2010: 2). Perancangan konsep pembelajaran diharapkan mampu menciptakan sumber daya manusia berkualitas dan mampu bekerja pada bidang tertentu (Saerozi, 2016: 43). Berdasarkan penjelasan yang telah dikemukakan dapat disimpulkan bahwa untuk menciptakan sumber daya manusia yang mampu bekerja pada satu pekerjaan khusus, kemampuan merancang tujuan pembelajaran yang bermakna dan dapat diterapkan merupakan kewajiban setiap guru. Perancangan pembelajaran khususnya SMK mengacu pada tujuan pendidikan kejuruan yang berfokus pada penguasaan pengetahuan, keterampilan, sikap, dan nilai-nilai. Penguasaan pengetahuan, keterampilan, sikap, dan nilai-nilai mengacu konsep kebutuhan pada dunia kerja (Atmawati, Samsudi, \& Sudana, 2017: 1) Selain itu, untuk mencapai tujuan pendidikan kejuruan, penentuan kompetensi dasar merupakan salah satu pondasi penting dalam desain pembelajaran yang berfungsi untuk membimbing peserta didik saat mengikuti kegiatan pembelajaran (Piskurich, 2015: 128). Berdasarkan pendapat di atas dapat disimpulkan bahwa tujuan pembelajaran yang dirancang sesuai dengan kebutuhan tujuan pendidikan pada masing-masing jenjang atau instansi sekolah dapat mewujudkan penguasaan yang diharapkan untuk dikuasai peserta didik. Merancang konsep pembelajaran diawali dengan merumuskan tujuan pembelajaran. Rumusan tujuan pembelajaran dijabarkan pada
RPP yang berfokus pada penguasaan pengetahuan, keterampilan, sikap, dan nilainilai. Penjabaran jumlah tujuan pembelajaran pada RPP mengacu pada kriteria-kriteria tertentu sesuai dengan karakteristik sekolah. Pembahasan mengenai esensi desain tujuan pembelajaran adalah sebagai berikut:

\section{Perumusan Tujuan Pembelajaran}

Tujuan pembelajaran merupakan tanggung jawab guru yang harus dipilih dan ditentukan dengan hati-hati untuk menciptakan proses pembelajaran yang bermakna (Isman, 2011: 136). Komponen audience, behavior, condition, dan degree merupakan pertimbangan untuk merumuskan tujuan pembelajaran yang sesuai dengan lingkungan pembelajaran. Komponen audience adalah salah satu unsur tujuan pembelajaran dengan mempertimbangkan peserta didik yang akan melakukan kegiatan belajar. Setiap peserta didik memiliki potensi sebelum masuk dalam kegiatan belajar mengajar. Potensi bawaan yang dimiliki peserta didik dipertimbangkan dalam merumuskan tujuan pembelajaran (Mudlofir \& Rusdiyah, 2016: 34-35). Komponen behavior adalah salah satu unsur tujuan pembelajaran dengan mempertimbangkan perilaku khusus yang akan dikuasai oleh peserta didik setelah melakukan kegiatan belajar.

Komponen condition adalah salah satu unsur tujuan pembelajaran dengan mempertimbangkan kondisi peserta didik dan fasilitas yang digunakan. Kondisi sekolah yang mendukung penerapan tujuan pembelajaran dapat meningkatkan hubungan antara guru dan peserta didik (Khuana \& Khuana, 2017: 302). Komponen degree adalah salah satu unsur tujuan pembelajaran dengan mempertimbangkan tingkat keberhasilan peserta didik yang diharapkan (Dick \& Carey, 2015: 132-133). Teori tujuan pembelajaran Dick and Carey yang memiliki unsur audience, behavior, condition, dan degree selaras dengan pengembangan tujuan pembelajaran pada kurikulum 2013. Tujuan pembelajaran pada kurikulum 2013 dikembangkan dengan 
memerhatikan audience yang berarti peserta didik yang menjadi subjek belajar, behavior mengacu pada capaian perilaku khusus pada kompetensi dasar, condition merupakan usaha belajar yang dapat membantu peserta didik untuk mencapai perilaku pembelajaran pada kompetensi dasar, dan degree merupakan kualitas keberhasilan peserta didik yang dapat dinyatakan secara kualitatif maupun kuantitatif.

\section{Penentuan Capaian Hasil Belajar}

Tujuan pembelajaran adalah hasil belajar yang diperoleh peserta didik setelah proses pembelajaran untuk satu topik pembelajaran pada satu periode tertentu (Tung, 2017: 19). Teori tujuan pembelajaran yang telah dikemukakan selaras dengan perumusan tujuan pembelajaran pada kurikulum 2013. Pada kurikulum 2013 untuk mengetahui hasil belajar peserta didik di akhir proses pembelajaran perumusan tujuan pembelajaran mengacu pada kompetensi dasar. Hasil belajar peserta didik dicerminkan oleh penguasaan kompetensi dasar untuk satu periode tertentu pada satu mata pelajaran. Untuk mencapai hasil belajar yang efektif dan efisien guru dituntut untuk dapat membantu peserta didik secara induktif dengan menyusun skema kognitif dari pengalaman konkrit mereka (Merrienboer \& Kirschner, 2018: 56). Berdasarkan pembahasan yang telah dijabarkan maka perumusan tujuan pembelajaran erat kaitannya dengan penetapan capaian hasil belajar yang diharapkan, pada kurikulum 2013 capaian hasil belajar yang diharapkan mengacu pada kompetensi dasar. Hasil belajar peserta didik yang maksimal dapat diperoleh melalui perancangan pembelajaran yang tersusun secara sistematis dan konsisten.

Tujuan pembelajaran dikembangkan secara spesifik dan jelas dengan menentukan satu perilaku yang dilakukan oleh peserta didik setelah melaksanakan kegiatan belajar mengajar (Dick \& Carey, 2015: 6). Tujuan pembelajaran yang mengembangkan satu perilaku yang spesifik dan jelas dapat memberikan keuntungan kepada peserta didik untuk mengatur waktu dan pemusatan perhatian terhadap kompetensi yang akan dikuasai. Teori Dick and Carey selaras dengan pengembangan tujuan pembelajaran pada kurikulum 2013 yang menggunakan satu kata kerja operasional untuk satu perilaku pada satu tujuan pembelajaran. Kata kerja operasional pada tujuan pembelajaran mengacu pada kompetensi dasar yang ditujukan untuk satu topik pembelajaran pada satu periode tertentu. Guru dapat menargetkan kompetensi dasar yang lebih tinggi melebihi level kemampuan peserta didik, hal ini dapat menciptakan pembelajaran yang kolaboratif dan interaktif (Paolini, 2015: 30). Berdasarkan penjelasan yang telah dikemukakan dapat disimpulkan bahwa pemilihan kompetensi dasar yang memiliki target tinggi melibihi batas minimal yang disyaratkan merupakan wujud kesiapan guru yang sangat optimis untuk mencapai hasil belajar yang maksimal.

Rumusan tujuan pembelajaran menggunakan kata kerja operasional untuk mengamati perilaku peserta didik. Penggunaan kata kerja operasional yang tepat dapat mengukur perilaku peserta didik di akhir proses pembelajaran (Dick \& Carey, 2015: 117-118). Teori tujuan pembelajaran Dick and Carey untuk penggunaan kata kerja operasional selaras dengan perumusan tujuan pembelajaran pada kurikulum 2013 Penggunaan kata kerja operasional untuk perumusan tujuan pembelajaran kurikulum 2013 mengacu pada kompetensi dasar yang telah diuraikan sesuai dengan Peraturan Menteri Pendidikan dan Kebudayaan (Permendikbud) Republik Indonesia Nomor 37 Tahun 2018 tentang kompetensi inti dan kompetensi dasar. Berdasarkan pembahasan yang telah dijabarkan dapat disimpulkan bahwa kata kerja operasional yang digunakan mencermikan perilaku peserta didik yang harus dilakukan sebagai wujud pencapaian hasil belajar yang telah diperoleh. Pencapaian hasil belajar peserta didik dapat disesuaikan dengan tingkatan peserta didik yang diawali dengan kemampuan yang mudah hingga kompleks. Kemampuan diawali dengan mengetahui, memahami, menerapkan, 
menganalisis, mensintesis, dan mengevaluasi (Moore, 2015: 196-197). Kemampuan peserta didik dapat diketahui melalui pencapaian aspek kognitif, aspek psikomotor, dan aspek afektif. Aspek kognitif meliputi: (1) mengingat ialah proses penarikan memori dan ingatan jangka panjang berupa menjelaskan, mengutip, menyebutkan, menggambarkan, mengidentifikasi, membilang, menandai, memberi nama dan menjodohkan; (2) memahami ialah menyesuaikan keahlian dan ilmu baru dalam pola pikir siswa berupa meringkas, menafsirkan, membandingkan, dan membuat klasifikasi; (3) menerapkan ialah menyelesaikan masalah sesuai prosedur meliputi mengimplementasikan dan menjalankan; (4) menganalisis ialah penentuan hubungan dan penguraian permasalahan berupa mengorganisasi, menemukan dan menguraikan; (5) mengevaluasi ialah menciptakan pertimbangan sesuai kriteria dan standar berupa mengkritik dan memeriksa; dan (6) menciptakan ialah membuat kesatuan dengan mengintegrasikan beberapa unsur berupa perencanaan, produksi, dan pembuatan. Aspek prikomotor meliputi: (1) pandangan, (2) menyiapkan, (3) mencontoh, (4) membiasakan, (5) menyesuaikan, dan (6) menciptakan. Aspek afektif meliputi: (1) menerima ialah sikap kepekaan siswa terhadap keadaan, fenomena, dan situasi, (2) memberi respon ialah sikap siswa saat berpartisipasi dan menanggapi ketika proses pembelajaran berlangsung, memberikan nilai ialah sikap saat memberikan kepercayaan atau penilaian terhadap suatu kondisi, fenomena atau gejala, mengorganisasi ialah keahlian untuk mengatur, mengelola, dan mengelaborasi nilai dalam sistem yang terstruktur, dan (5) karakterisasi nilai adalah kemampuan mengatur pedoman berperilaku melalui pengembangan pandangan pribadi. Penggunaan kata kerja operasional dapat mengikutsertakan perilaku pembelajaran yang mendorong kemampuan tingkat tinggi yang dimiliki peserta didik (Kistner et al., 2015: 193). Selain itu, dapat pula mempertimbangkan kecerdasan, profil, minat, kesiapan, dan multikulturalisme yang dimiliki peserta didik (Hamm \& Adams, 2009: 111). Berdasarkan penjelasan mengenai penggunaan kata kerja operasional yang telah dijabarkan, maka dapat disimpulkan bahwa pemilihan kata kerja operasional sangat dipengaruhi oleh karakteristik peserta didik. Sebelum menetapkan kata kerja operasional yang digunakan guru dapat melakukan analisis kebutuhan yang dapat menjadi bahan pertimbangan. Penggunaan kata kerja operasional pada tujuan pembelajaran berpengaruh pada proses penilaian yang dilakukan oleh guru. Pemilihan kata kerja operasional yang tepat pada tujuan pembelajaran memudahkan guru untuk menilai kegiatan peserta didik dan penyusunan tes. Capaian hasil belajar peserta didik dapat dilakukan melalui pemberian tugas yang mengikuti perkembangan zaman sehingga memungkinkan peserta didik untuk menjadi lebih terampil dan inovatif (Ibrahim \& Aziz, 2012: 610). Selain itu, pemberian tugas berbasis pada dunia kerja dapat mengembangkan pemikiran kritis, mandiri, dan aktif pada peserta didik (Ganefri \& Hidayat, 2015: 210). Berdasarkan penjelasan di atas dapat disimpulkan bahwa pemilihan kata kerja operasioanal memberikan persoalan kepada guru untuk dapat merumuskan tujuan pembelajaran yang menimbang proses penilaian peserta didik.

\section{Relevansi Perangkat Pembelajaran}

Merancang tujuan pembelajaran hendaknya dapat mewujudkan kegiatan yang sistematis, praktis, efektif, dan tepat (Sesiorina, 2014: 88). Tujuan pembelajaran yang dirancang dituntut utnuk mempertimbangkan perangkat pembelajaran yang tersedia di sekolah dan mempertimbangkan keadaan peserta didik. Pemilihan perangkat pembelajaran seperti media, alat, dan sumber belajar sangat erat kaitannya dengan perwujudan kondisi pembelajaran yang diharapkan. Pemilihan perangkat pembelajaran yang tepat guna merupakan cerminan kesiapan guru dalam 
menyusun media, alat, dan sumber belajar yang berdampak pada perubahan tingkah laku peserta didik, sehingga keselarasan antara perangkat pembelajaran yang digunakan dengan tujuan pembelajaran cenderung diperkuat (Mudlofir \& Rusdiyah, 2016: 121-128). Berdasarkan pembahasan di atas, maka dapat disimpulkan bahwa perumusan tujuan pembelajaran hendaknya relevan dengan kondisi perangkat pembelajaran yang tersedia di sekolah dan relevan dengan keadaan peserta didik. Pertimbangan ini sangat penting karena sarana dan prasana sekolah yang lengkap dapat membantu peserta didik mencapai hasil belajar.

\section{Implementasi Tujuan Pembelajaran}

2013 Tujuan $\begin{array}{lr}\text { pembelajaran pada kurikulum } \\ \text { dikembangkan }\end{array}$ mempertimbangkan kesanggupan peserta didik dan guru untuk merepresentasikan tujuan pembelajaran secara nyata. Aktivitas yang dicerminkan pada tujuan pembelajaran mempertimbangkan motivasi, keadaan peserta didik, kompleksitas tugas, dan lingkungan (Dick \& Carey, 2015: 122-144). Pertimbangan aktivitas tujuan pembelajaran tersebut sama halnya dengan teori belajar behavioristik yang mengemukakan bahwa kemampuan guru mengelola hubungan antara stimulus dengan respon pada situasi pembelajaran dapat mengoptimalkan hasil belajar peserta didik (Mudlofir \& Rusdiyah, 2016: 1). Berdasarkan penjelasan yang telah dikemukakan dapat disimpulkan bahwa tujuan pembelajaran tidak hanya sebagai rancangan berupa tulisan, tetapi hendaknya diwujudkan secara nyata di kelas. Guru yang mengutamakan perancangan tujuan pembelajaran yang dapat diterapkan di kelas dapat meningkatkan kualitas pembelajaran (Nesari \& Heidari, 2014: 28). Untuk mewujudkan proses pembelajaran yang sesuai tujuan pembelajaran, guru dapat menganalisis konsep pembelajaran sebelumnya sebagai dasar untuk mempelajari konsep pembelajaran yang baru (Yildiz \& Karabiyik, 2012: 4025). Selain itu, guru dapat menganalisis kompetensi, karakteristik peserta didik, pengalaman belajar dan motivasi, situasi belajar, dan sumber belajar (Alzand, 2010: 4080). Berdasarkan pendapat para ahli yang telah dikemukakan dapat disimpulkan bahwa untuk mewujudkan tujuan pembelajaran secara nyata di kelas guru dapat mempelajari pengalaman pembelajaran yang telah dilakukan sebelumnya. Hasil pengamatan tersebut dapat menjadi bahan pertimbangan untuk merancang tujuan pembelajaran yang optimal jika diwujudkan didalam kelas.

\section{METODE}

Penelitian ini menjadikan dokumen RPP sebagai subjek. Penelitian yang menggunakan dokumen sebagai subjek tergolong ke dalam analisis isi. Sumber data pada peneliti ini didapatkan melalui dokumen RPP guru Kompetensi Keahlian Teknik Instalasi Tenaga Listrik pada Mata Pelajaran Dasar Listrik dan Elektronika SMK Negeri di Kota Yogyakarta yang mengikuti perkembangan kurikulum 2013. Sumber data dikhususkan pada dokumen RPP mata pelajaran dasar listrik dan elektronika yang memiliki kesesuaian dengan kompetensi dasar yang mengacu pada Permendikbud Republik Indonesia Nomor 37 Tahun 2018 tentang kompetensi inti dan kompetensi dasar. Jumlah RPP oleh satu guru mata pelajaran dasar listrik dan elektronika dari SMK Negeri 3 Yogyakarta adalah 20 dokumen. Jumlah RPP oleh satu guru mata pelajaran dasar listrik dan elektronika dari SMK Negeri 2 Yogyakarta adalah 9 dokumen. Jumlah RPP oleh satu guru Mata Pelajaran Dasar Listrik dan Elektronika dari SMK Muhammadiyah 3 Yogyakarta adalah 10 dokumen. Instrumen pada penelitian analisis isi disebut sebagai lembar coding (Coding sheet). Kisi-kisi intrumen ditampilkan pada Tabel 1. 
Tabel 1. Kisi-kisi Instrumen

\begin{tabular}{ll}
\hline \multicolumn{1}{c}{ Variabel Analisis } & \multicolumn{1}{c}{ Sub Variabel Analisis } \\
\hline Tujuan pembelajaran dengan & Tujuan pembelajaran menimbang peserta didik yang diajar \\
kompetensi dasar. & (Audience). \\
& Tujuan pembelajaran menimbang perilaku pembelajaran \\
pada KD (Behavior). & Tujuan pembelajaran menimbang kondisi pembelajaran \\
& yang dapat membantu peserta didik mencapai perilaku \\
pembelajaran (Condition) & Tujuan pembelajaran menimbang tingkat keberhasilan yang \\
& diharapkan (Degree) \\
Tujuan pembelajaran mencakup pengembangan \\
pengetahuan dan keterampilan
\end{tabular}

Validitas dilakukan oleh 4 dosen, dosen memberikan pendapat dan penilaian mengenai lembar coding yang telah disusun oleh peneliti. Penelitian ini menggunakan desain reliabilitas reproduksibilitas yang akan menilai sejauh mana sebuah alat ukur dapat menghasilkan temuan yang sama dalam keadaan yang berbeda, dilokasi yang berbeda, dan coder yang berbeda. keselarasan kompetensi dasar dengan tujuan pembelajaran diwakilkan oleh 5 pernyataan. Reliabilitas pada penelitian ini menggunakan formula Cohen Kappa, rumus ini digunakan karena perhitungan reliabilitas antar coder yang menggunakan Cohen Kappa didasarkan pada peluang (Chance) dari masingmasing kategori yang digunakan alat ukur. Reliabilitas pada penelitian ini menggunakan formula Cohen Kappa, rumus ini digunakan karena perhitungan reliabilitas antar coder yang menggunakan Cohen Kappa didasarkan pada peluang (Chance) dari masing-masing kategori yang digunakan alat ukur. Uji realibitas dengan hasil kategori baik menandakan persetujuan antar coder memiliki kesamaan yang cukup tajam. Uji realibitas dengan hasil kategori kuat menandakan persetujuan antar coder memiliki kesamaan yang tajam. Teknik analisis data pada penelitian ini menggunakan pendekatan statistik deskriptif.

\section{HASIL DAN PEMBAHASAN}

Keselarasan tujuan pembelajaran dengan kompetensi dasar merupakan indikator tingkat kualitas RPP yang diukur dengan keterwakilan pernyataan sebanyak 5 butir dari total pernyataan sebanyak 35 butir. Pengukuran dilakukan dengan mengisi lembar coding oleh coder yang dikelompokkan berdasarkan pengkategorian sangat sesuai bernilai 4 , sesuai bernilai 3, kurang sesuai bernilai 2, dan tidak sesuai bernilai 1. Variabel keselarasan tujuan pembelajaran dengan kompetensi dasar yang diwakilkan oleh 5 butir pernyataan dapat menghasilkan skor tertinggi bernilai 20 dan skor terendah bernilai 5. Setelah mengetahui skor tertinggi dan skor terendah untuk 5 butir pernyataan, maka analisis selanjutnya adalah menentukan nilai Mean ideal (Mi) dan nilai Standar Deviasi ideal (SDi). Berdasarkan perhitungan nilai Mi dan nilai SDi maka dapat diidentifikasi kecenderungan data keselarasan tujuan pembelajaran dengan kompetensi dasar ditunjukkan pada Tabel 2.

Tabel 2. Kecenderungan Data Keselarasan Tujuan Pembelajaran dengan Kompetensi Dasar

\begin{tabular}{ll}
\hline \multicolumn{1}{c}{ Kategori } & \multicolumn{1}{c}{ Persentase $(\%)$} \\
\hline Sangat Sesuai & 17,95 \\
Sesuai & 51,28 \\
Kurang Sesuai & 30,77 \\
Tidak Sesuai & 0,00 \\
\hline
\end{tabular}


Berdasarkan Tabel 2 dapat dijelaskan bahwa nilai keselarasan tujuan pembelajaran dengan kompetensi dasar paling banyak terdapat pada kategori sesuai dengan persentase $51,28 \%$. Nilai mean digunakan untuk menggambarkan rata-rata, dan menyimpulkan hasil pengukuran keselarasan antara desain tujuan pembelajaran dengan kompetensi dasar RPP setiap SMK. Total nilai mean SMK Negeri 3 Yogyakarta ialah 15,2 (76,00\%) dengan kategori sesuai. Total nilai mean SMK Negeri 2 Yogyakarta ialah 12,22 (61,00\%) dengan kategori kurang sesuai. Total nilai mean SMK Muhammadiyah 3 Yogyakarta ialah 11,6 $(58,00 \%)$ dengan kategori kurang sesuai. Total nilai mean RPP setiap SMK dapat dikalkulasi sehingga menghasilkan kesimpulan tingkat keselarasan tujuan pembelajaran dengan kompetensi dasar di Kota Yogyakarta. Hasil kalkulasi total nilai mean RPP seluruh SMK di Kota Yogyakarta ialah sebesar 13,01 (65,03\%) dengan kategori sesuai. Hasil keselarasan tujuan pembelajaran dengan kompetensi dasar berkategori sesuai dapat dijelaskan secara rinci melalui telaah dokumen RPP oleh coder yang mengacu pada hasil analisis data. Berdasarkan analisis data yang telah dijabarkan, maka pembahasan aspek keselarasan tujuan pembelajaran dengan kompetensi dasar dapat diuraikan sebagai berikut. Pertama, hasil telah ditemukan rata-rata guru mencantumkan peserta didik yang diajarkan untuk satu kompetensi dasar, hal ini merupakan cerminan jika tujuan pembelajaran yang dirancang guru menimbang peserta didik yang diajar. Kedua, ditemukan rata-rata guru menggunakan kata kerja operasional, hal ini merupakan cerminan jika tujuan pembelajaran yang dirancang guru menimbang perilaku pembelajaran yang diharapkan untuk mencapai kompetensi dasar. Ketiga, ditemukan rata-rata guru mencantumkan kondisi pembelajaran yang dapat membantu peserta didik mencapai perilaku pembelajaran, hal ini merupakan cerminan jika tujuan pembelajaran yang dirancang guru menimbang terwujudnya kondisi pembelajaran sesuai kata kerja operasional untuk mencapai perilaku pembelajaran. Keempat, ditemukan rata-rata guru mencantumkan tingkat keberhasilan yang diharapkan sesuai kondisi pembelajaran, hal ini merupakan cerminan jika tujuan pembelajaran yang dirancang guru menimbang tingkat keberhasilan sesuai kondisi pembelajaran yang diterapkan. Kelima, ditemukan kata kerja operasional pada kompetensi dasar pengetahuan dan keterampilan rata-rata di bawah batas minimal level kemampuan peserta didik kelas $\mathrm{X}$, hal ini menunjukkan bahwa tujuan pembelajaran yang dirancang guru kurang menimbang perilaku pembelajaran yang sesuai untuk level kemampuan peserta didik kelas $X$ pada kompetensi dasar pengetahuan dan keterampilan. Penyajian data keselarasan tujuan pembelajaran dengan kompetensi dasar untuk setiap butir pernyataan ditunjukkan pada histogram Gambar 1.

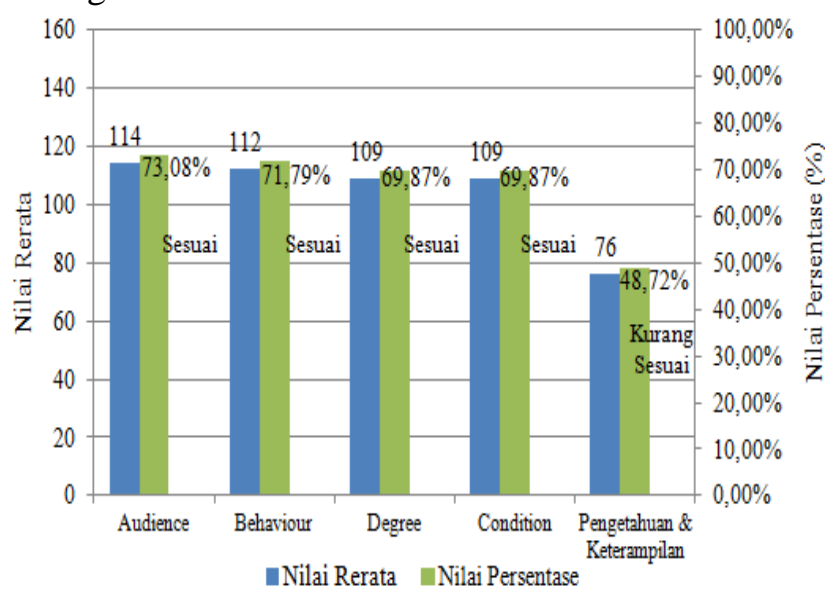

Gambar 1. Keselarasan Tujuan Pembelajaran dengan Kompetensi Dasar Setiap Butir Pernyataan.

Keselarasan antara desain tujuan pembelajaan dengan kompetensi dasar diinterpretasikan melalui pernyataan-pernyataan yaitu, pada butir pernyataan pertama, tujuan pembelajaran menimbang peserta didik yang diajar (Audiens) memperoleh nilai 114 $(73,08 \%)$ dengan kategori sesuai. Butir pernyataan kedua yaitu, tujuan pembelajaan menimbang perilaku pembelajaran pada KD (Behavior) memperoleh nilai 112 atau $(71,79 \%)$ dengan kategori sesuai . Butir pernyataan ketiga 
yaitu, tujuan pembelajaan menimbang kondisi pembelajaran yang dapat membantu peserta didik mencapai perilaku pembelajaran (Condition) memperoleh nilai 109 (69,87\%) dengan kategori sesuai. Butir pernyataan keempat yaitu, tujuan pembelajaan menimbang tingkat keberhasilan yang diharapkan (Degree) memperoleh 109 (69,87\%) dengan kategori sesuai, dan butir pernyataan kelima yaitu, tujuan pembelajaan mencakup pengembangan pengetahuan dan keterampilan memperoleh nilai $76(48,72 \%)$ dengan kategori kurang sesuai.

Berdasarkan Gambar 1 dapat dijelaskan bahwa pernyataan 1 yang menilai tujuan pembelajaan menimbang peserta didik yang diajar (Audiens) mendapatkan nilai tertinggi yaitu $114(73,08 \%)$ dengan kategori sesuai, sedangkan pernyataan 5 yang menilai tujuan pembelajaan mencakup pengembangan pengetahuan dan keterampilan mendapatkan nilai terendah yaitu $76(48,72 \%)$ dengan kategori kurang sesuai.

\section{SIMPULAN}

Berdasarkan pembahasan hasil penelitian tentang analisis perancangan pembelajaran guru teknik instalasi tenaga listrik SMK di Kota Yogyakarta, dapat disimpulkan yaitu keselarasan antara desain tujuan pembelajaran dengan kompetensi dasar pada RPP mata pelajaran dasar listrik dan elektronika masuk pada kategori sesuai dengan penunjukkan persentase nilai rata-rata sebesar $65,03 \%$. Keselarasan antara desain tujuan pembelajaran dengan kompetensi dasar pada RPP mata pelajaran dasar listrik dan elektronika yang dirancang oleh guru memiliki keunggulan pada mendesain tujuan pembelajaran yang menimbang peserta didik yang diajar (Audience). Kekurangan terdapat pada mendesain tujuan pembelajaran yang mencakup pengembangan pengetahuan dan keterampilan.

\section{DAFTAR RUJUKAN}

Alzand, W. (2010). Instruction Design and Educational Quality. Procedia Social and Behavioral Sciences 2, 4074-4081. Published by Elsevier Ltd. doi: 10.1016/j.sbspro.2010.03.643.

Atmawati, Samsudi., \& Sudana. I. M. (2017). Keefektifan Pelaksanaan Praktek Kerja Lapangan Berbasis Industri pada Kompetensi Keahlian Teknik Audio Video. Journal of Vocational and Career Education, 2(2), 1-8. Retrieved from https://journal.unnes.ac.id/nju/index.php/j vce/article/download/13809/75 62.

Bariyah, L. (2014). Analisis Kesesuaian RPP dan Pelaksanaan Pembelajaran Guru SMPN di Kabupaten Mojokerto pada Sub Materi Fotosintesis dengan Kurikulum 2013. Bio Edu Berkata Ilmiah Pendidikan Biologi, 3(3), 453- 460. Retrieved from http://ejournal.unesa.ac.id/index.php/bioe du.

Brown, A. H., \& Green, T. D. (2016). The Essentials of Instructional Design: Connecting Fundamental Principles with Process and Practice. Routledge, New York.

Dick, W. L., \& Carey, J. O. (2015). The Systematic Design of Instructional (8th ed). The United Stade of America: Pearson.

Ganefri \& Hidayat, H. (2015). Production Based Learning: An Instructional Design Model in The Context of Vocational Education and Training (VET). Procedia Social and Behavioral Sciences 204, 206211. Published by Elsevier Ltd. doi: 10.1016/j.sbspro.2015.08.142.

Hamm, M., \& Adams. D. A. (2009). Activating Assessment for All Student. United Kingdom, Rowman \& littlefield publisher. 
Haynes, A. (2010). The Complete Guide to Lesson Planning and Preparation. New York, Continuum international publishing group.

Ibrahim, Z., \& Aziz, A. A. (2012). Instructional Design Theory on Teaching Delivery and Evaluation Online for Graphic Design Courses. Procedia Social and Behavioral Sciences 67, 606-610. Published by Elsevier Ltd. doi: 10.1016/j.sbspro.2012.11.366.

Isman, A. (2011). Instructional Design in Education: New Model. TOJET: The Turkish Online Journal of Educational Technology, 10(1), 136-142. tojet.net/articles/v10i1/10114.pdf.

Khuana, K., \& Khuana. T. (2017). Impressive Learning Strategies with Indoctrinating Research-Based to Creative Thinking Skills for Educational Students. European Journal of Eduvcation Studies, 3(2), 288-304. doi: 10.5281/zenodo.260008.

Kistner, S., Rakoczy, K., Otto, B., Klieme, E., \& Buttner, G. (2015). Teaching Learning Strategies: The Role of Instructional Context and Teacher Beliefs. Journal for Educational Research Online: Journal für Bildungsforschung Online, 7(1), 176197. URN: urn:nbn:de:0111-pedocs110527.

Merrienboer, J. G. V., \& Kirschner. P. A. (2018). Learning: A Systematic Approach to Four-Component Instructional Design. New York, Routledge.

Moore, K. D. (2015). Effective Instructional Strategies from Teory to Practice. (4th ed.). Los Angeles: SAGE Publication USA

Mudlofir, A., \& Rusydiyah. E. F. (2016). Desain Pembelajaran Inovatif dari Teori ke Praktik. Jakarta: Rajagrafindo Persada.
Nesari, A. J. (2014). The Important Role of Lesson Plan on Educational Achievement of Iranian EFL Teachers' Attitudes. International Journal of Foreign Language Teaching \& Research, 3(5), 25-31. jfl.iaun.ac.ir/article_10884.html.

Paolini, A. (2015). Enhancing Teaching Effectiveness and Student Learning Outcomes. The Journal of Effective Teaching: An Online Journal Devoted to Teaching Excellence, 15(1), 20-33. https://uncw.edu/jet/articles/Vol15 1/Vol ume1501.pdf.

Peraturan Menteri Pendidikan dan Kebudayaan Republik Indonesia Nomor 37 Tahun 2018 Tentang Kompetensi Inti dan Kompetensi Dasar.

Piskurich, G. M. (2015). Rapid Instructional Design: Learning ID Fast and Right. New Jersey, John Wiley \& Sons, Inc.

Sa'diyah, M., \& Mujahidin, E. (2015). Upaya Membangun Budaya Akademik Guru Madrasah (Sebuah Langkah Awal). Jurnal Online Universitas Ibn Khaldun, 66-80. Retrieved from http://ejournal.uikabogor.ac.id/index.php/ FIKRAH/article/download/118/116.

Saerozi. (2017). Pengaruh Model Pembelajaran Project Based Learning Berorientasi Ecopreneurship dan Motivasi Terhadap Peningkatan Hasil Belajar Siswa pada Materi Sistem Pengelasan di Sekolah Menengah Kejuruan. Jurnal Pendidikan Teknik Mesin, 17(1), 43-49. Retrieved from

https://journal.unnes.ac.id/nju/index.php/ JPTM/article/download/12735/7 281.

Sesiorina, S. (2014). The Analysis of Teachers' Lesson Plan in Implementing Theme based Instruction for Teaching English to Young Learners. Journal of English and Education, 2(1), 84-95. http://ejournal.upi.edu/index.php/LE/artic le/view/750. 
Setyawanto, A., Sunaryo, H. S., \& Basuki, I. B. (2013). Rencana Pelaksanaan Pembelajaran (RPP) Guru Bahasa Indonesia Tingkat SMP di Kota Malang. Jurnal Online Universitas Negeri Malang, 1-11. Retrieved from http://jurnalonline.um.ac.id/data/artikel/ar tikelB75014B49ADF96FF1A3C8AA02E 0 89935.pdf

Tung, K. Y. (2017). Desain Instruksional Perbandingan Model dan
Implementasinya. Yogyakarta: Penerbit Andi. Yildiz, Z., \& Karabiyik. B. (2012). The Implementation of A Lesson Plan Which is Prepared According to The Meaningful Learning Theory and Evaluation of The Results. Procedia Social and Behavioral Sciences 46, 40214025. Published by Elsevier Ltd. doi: 10.1016/j.sbspro.2012.06.190. 